\begin{tabular}{|c|c|c|c|c|}
\hline Internat. Rev. Hydrobiol. & $\mathbf{8 9}$ & 2004 & $5-6$ & $453-466$ \\
\hline
\end{tabular}

\title{
DOI: 10.1002/iroh.200410764
}

\section{Ana Sampaio ${ }^{1 *}$, Rui Cortes ${ }^{2}$ and Cecília Leão ${ }^{3}$}

\author{
${ }^{1}$ CETAV - Departamento de Engenharia Biológica e Ambiental, University of Trás-os-Montes e \\ Alto Douro, Apartado 1013, 5001-911 Vila Real, Portugal; e-mail: asampaio@utad.pt \\ ${ }^{2}$ Departamento Florestal, University of Trás-os-Montes e Alto Douro, Apartado 1013, \\ 5001-911 Vila Real Codex, Portugal \\ ${ }^{3}$ Life and Health Sciences Research Institute, School of Health Sciences, University of Minho, \\ Campus de Gualtar, 4710-057 Braga, Portugal
}

\section{Yeast and Macroinvertebrate Communities Associated with Leaf Litter Decomposition in a Second Order Stream}

\author{
key words: yeast, ergosterol, invertebrates, leaf litter
}

\begin{abstract}
The composition of yeast and macroinvertebrate communities was studied on black alder, blue gum eucalyptus and English oak leaves decaying in a stream during a six-month period. ANOVA analysis showed significantly different values $(\mathrm{p}<0.0001)$ of yeast and macroinvertebrate densities among the three leaf litters. Some yeast species such as Cryptococcus albidus (SAITO), C. laurentii (Kufferath), Rhodothorula glutinis (FRESENIUS), R. colostri (CASTELLI), and Debaryomyces hansenii (LoDDER and KREGER-VAN RIJ) were present in all litter types. Other yeasts were restricted to a specific type of litter. Macroinvertebrates were dominated by collectors-gatherers on oak and eucalyptus leaves. Shredders reached highest densities in alder leaves.
\end{abstract}

\section{Introduction}

Leaf litter breakdown is a key process in low order streams (MinsHALL, 1967; ABELHO and GRAÇA, 1998). The decomposition rate of leaves entering the stream depends on abiotic factors such as temperature, flow, physical abrasion (PETERSEN and CuMMINS, 1974), $\mathrm{pH}$ (CHAMIER, 1987), nitrate and phosphate concentrations (PozO, 1993), and biotic factors such as initial litter quality (Melillo et al., 1984), invertebrate and microbial colonisation (ANDERSON and SEDELL, 1979). Leaf decay has traditionally been described as a sequential process, which proceeds from leaching to physical abrasion, microbial conditioning and invertebrate colonization. However, some authors (e.g., GESSNER et al., 1999) have suggested that these stages occur simultaneously and are interactive. They also propose that this interaction can involve competition for nutrients between fungi and shredder communities.

During breakdown, a succession of organisms occurs, reflecting an adjustment of biological communities to the surrounding environment (FRANKLAND, 1998). Succession studies during litter decay in aquatic systems have been confined to single biological groups such as macroinvertebrates (e.g., BASAGUREN and POZO, 1994; RoBINSON et al., 1998; CollieR and Halliday, 2000), and aquatic hyphomycetes (e.g., Chauvet et al., 1997). These asexual and filamentous fungi are often found on decomposing leaves, wood and twigs in wellaerated water bodies. Hyphomycetes have been identified in the early stages of litter decomposition, and proved to have a direct impact on decay, by synthesising cellulolytic, pectinolytic and proteolytic enzymes. Other studies have demonstrated their importance in

\footnotetext{
* Corresponding author
} 
changing the palatability and food quality of the leaves for shredders (BÄRLOCHER, 1985; GRAÇA et al., 1993).

In addition to filamentous fungi, yeast and yeast-like organisms are common inhabitants of aquatic environments (SPENCER et al., 1970). Whereas basidiomycetous yeasts appears ubiquitous, ascomycetous seem more responsive to the concentration of organic debris (LACHANCE and STARMER, 1998). Saprophytic yeasts are also common on the surfaces of leaves (JAGER et al., 2001), fruits (VENTURINI et al., 2002) and flowers (LACHANCE et al., 2001), with the most common genera being Candida, Cryptococcus, Pichia, Rhodotorula and Trichosporon. To date, only a few studies on yeast communities associated with leaf litter decay in streams have been conducted. Nevertheless, previous work (SAMPAIO et al., 2001) has demonstrated that yeast numbers differ among the litter types.

In terrestrial habitats, the relationships between yeasts and insects are well established (see LACHANCE et al., 2001 and references therein). In these habitats, yeasts have an important role in the food chain. Insects not only feed on the substrate known to serve as yeast habitats, but use yeast as food source. Yeasts convert simple nitrogenous compounds into proteins and other nutrients beneficial to insects (LACHANCE and STARMER, 1998).

Yeasts probably have a limited direct impact on leaf litter decay, since only a few are able to degrade cellulose (FlanNigAn, 1970; DenNis, 1972) and xylan (BIELY et al., 1978; JiMÉNEZ et al., 1991). Nevertheless, it is important, at least in an ecological context, to study the processes in which yeasts participate. Are yeast species sensitive to different litters and/or to changes during decay? Are aquatic invertebrate communities related to yeast populations? To answer these questions, we investigated the dynamics of yeast and invertebrate densities; and the species composition of yeast and macroinvertebrate communities.

\section{Materials and Methods}

\subsection{Study Area}

The study site was located in the Olo river basin, a second order stream, located in Serra do Alvão, Northeast Portugal. The watercourse is $40 \mathrm{~km}$ long, a catchment area of $143.8 \mathrm{~km}^{2}$ in an area of reduced human impact. The stream water is acidic $(\mathrm{pH} 5.5)$ and oligotrophic. Range values for several physical-chemical parameters of water quality in the study site were: water temperature $5.0-17.1^{\circ} \mathrm{C}$, dissolved oxygen $8.7-15.8 \mathrm{mgl}^{-1}$, conductivity $7.0-42.0 \mu \mathrm{S} \mathrm{cm}^{-1}, \mathrm{NO}_{3}^{-} 0.03-0.1 \mathrm{mgl}^{-1}$, $\mathrm{PO}_{4}^{3-} 0.004-0.05 \mathrm{mgl}^{-1}$ and $\mathrm{Cl}^{-} 0.9-2.0 \mathrm{mgl}^{-1}$. The geological substratum is dominated by granite in upstream reaches, and by schist and quartzite in middle and lower reaches. The riparian native vegetation is characterised by alder (Alnus glutinosa (L.) GAERTN.), willow (Salix atrocinerea Brot.), ash (Fraxinus angustifolia VAHL.) and oak (Quercus pyrenaica WILLD and Q. robur L.). Intensive forest plantations with exotic species such as pine (Pinus pinaster AIT. and P. sylvestris L.) and eucalyptus (Eucalyptus globulus LABILL.) trees are common in the lower reaches of this basin.

\subsection{Collection and Processing of Samples}

Litter decay experiments took place from January 1999 to August 1999, using leaves of A. glutinosa, E. globulus and Q. robur picked from the trees in mid October 1998. After collection, leaves were air dried at $40{ }^{\circ} \mathrm{C}$ (48 hours) and stored until use. Dried leaves were weighed ( $4.0 \pm 0.1 \mathrm{~g}$ per litterbag), rehydrated to prevent mass losses during transportation, and packed in 5-mm mesh litterbags. The sealed bags were attached to nylon ropes and firmly anchored to the streambed. After 1, 7, 14, 28, 56, 112 and 171 days of immersion, each litterbag was enclosed placed underwater in a sterilised plastic bag and transferred to the laboratory in a cool, dark box.

For each sampling period and litter type, six bags of each leaf species were collected. The contents of three bags were rinsed with tap water, macroinvertebrates were retrieved and preserved in $70 \%$ 
ethanol until identification. The bags were oven dried at $104{ }^{\circ} \mathrm{C}$ ( 48 hours) to obtain residual dry mass. Invertebrates were identified under a stereoscope to the lowest possible taxonomic level (except for Diptera, where identification extended only to the family or sub-family level). The insects were further categorised into functional feeding groups (Cummins and Klug, 1979; MERRIT and Cummins, 1984).

The remaining bags were used to determine yeast numbers, as explained by SAMPAIO et al. (2001) and ergosterol content. Microbial densities was expressed by number of colony forming units (CFU) per dry litter mass. Yeast colonies (sampled arbitrarily) were isolated by streaking on yeast malt dextrose agar (DIFCO Laboratories, Detroit, U.S.A.). After isolation, the yeast strains were stored at $4{ }^{\circ} \mathrm{C}$ until identification. This was done by physiological, morphological and biochemical characterisation according to the techniques described by YARROW (1998). All yeast isolates were identified to species level except the "black yeasts" group.

To estimate fungal biomass by the extraction and quantification of ergosterol, we followed the procedures of GESSNER and SCHMITT (1996). Approximately $50 \mathrm{mg}$ of freshly lyophilised leaf were used to extract ergosterol by heating $\left(80^{\circ} \mathrm{C}\right)$ in alkaline methanol during $30 \mathrm{~min}$. After purification of the crude extract by solid-phase extraction (Waters Sep-Pak ${ }^{\circledR} \mathrm{tC} 18,500 \mathrm{mg}$ ), ergosterol was quantified by highperformance liquid chromatography (HPLC) with a UV-detector. The HPLC analysis was performed with a reverse phase column: LiChrospher RP18 (25-cm length, 4-mm inner diameter and $5 \mu \mathrm{m}$ particle size). Chromatography was performed under the following conditions: 100\% methanol (HPLC grade) as the mobile phase, $1.4 \mathrm{ml} / \mathrm{min}$ of flow rate, $33{ }^{\circ} \mathrm{C}$ for column temperature, absorbance of $282 \mathrm{~nm}$, and the injection volume of $10 \mu \mathrm{l}$. A calibration curve (based on area peaks) was prepared with pure ergosterol (Fluka) extracts.

\subsection{Data Analysis}

To determine statistical differences between leaf species and incubation periods, yeast and total macroinvertebrate, functional feeding-groups densities and ergosterol concentrations were transformed $\left[\log _{10}(\mathrm{x}+1)\right]$ and analysed with factorial ANOVA (STATVIEW, 1992-1996). Pearson's correlation analysis was also performed in this program.

For multivariate analysis, the yeast species data were organised in a matrix. The absence of species was recorded as 0 , whereas the presence was recorded as the percent frequency of isolation (PFI). This value is the number of positive records of yeast specie divided by the total number of isolates in a sample. Also, the invertebrate species data were transformed $\left[\log _{10}(x+1)\right]$; single occurrences of a taxon were excluded.

Multiple discriminant analysis (MDA), using a forward stepwise procedure, followed by a canonical analysis (CA) were used to determine which variables (invertebrates or yeast taxa) discriminate between a priori defined groups of samples. Such groups were leaf species (alder, eucalyptus and oak) and stage of colonisation ( $1^{\text {st }}$ stage: days 1 and 7; $2^{\text {nd }}$ stage: days 14 and 28; $3^{\text {rd }}$ stage: days 56,112 and 171). Therefore, a total of four distinct MDAs were computed taking in account the two types of organisms and the two types of sample aggregation. These analyses were performed with STATISTICA ${ }^{\text {TM }}$ (1999).

\section{Results}

\subsection{Yeast Colonisation}

At the beginning of the experiment, before immersion in the stream, none of the litter types had any yeasts (Fig. 1). Yeast densities clearly differed among the three leaves. In oak litter, yeast counts remained essentially constant from day 1 throughout the entire experimental periods, whereas in eucalyptus leaves yeast densities increased from day 56 to the end of the experiment. Yeast colonisation of alder exhibited greater fluctuations when compared to the other species. Both litter type $(\mathrm{F}=55.65, \mathrm{p}<0.0001)$ and the length of immersion $(\mathrm{F}=27.54, \mathrm{p}<0.0001)$ affected yeast numbers.

In total, 36 yeast species were isolated. Alder litter yielded highest number of species (22), followed by eucalyptus (20) and by oak (18). Basidiomycetous yeasts accounted for $50 \%$ 


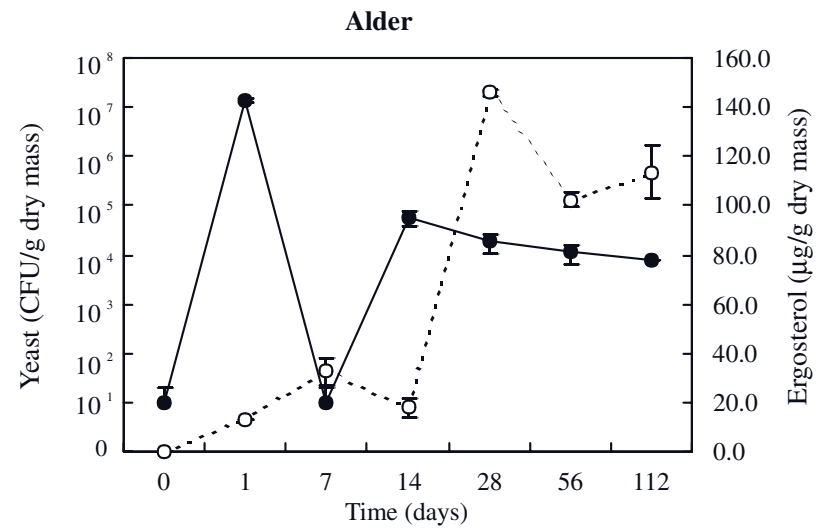

Oak
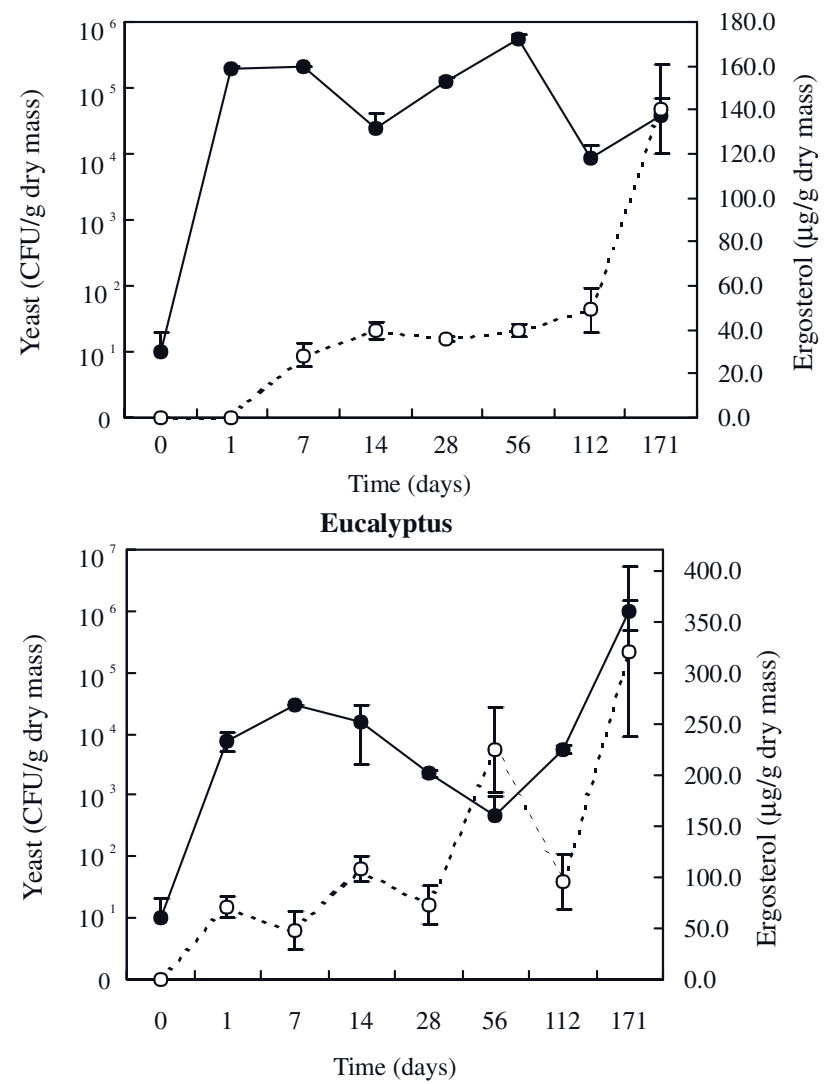

Figure 1. Yeast (solid line) and ergosterol (dot line) dynamics during decomposition in alder, oak and eucalyptus leaves (mean $\pm \mathrm{SD}, \mathrm{n}=3$ ). Yeast colony forming units (CFU) are on a semi-logarithmic scale.

(alder) or more (oak and eucalyptus) of the total number of species found (Fig. 2). Some species common to all three leaves were Cryptococcus albidus, C. laurentii, Rhodothorula glutinis, R. colostri and Debaryomyces hansenii (Fig. 2). Others species were restricted to a 

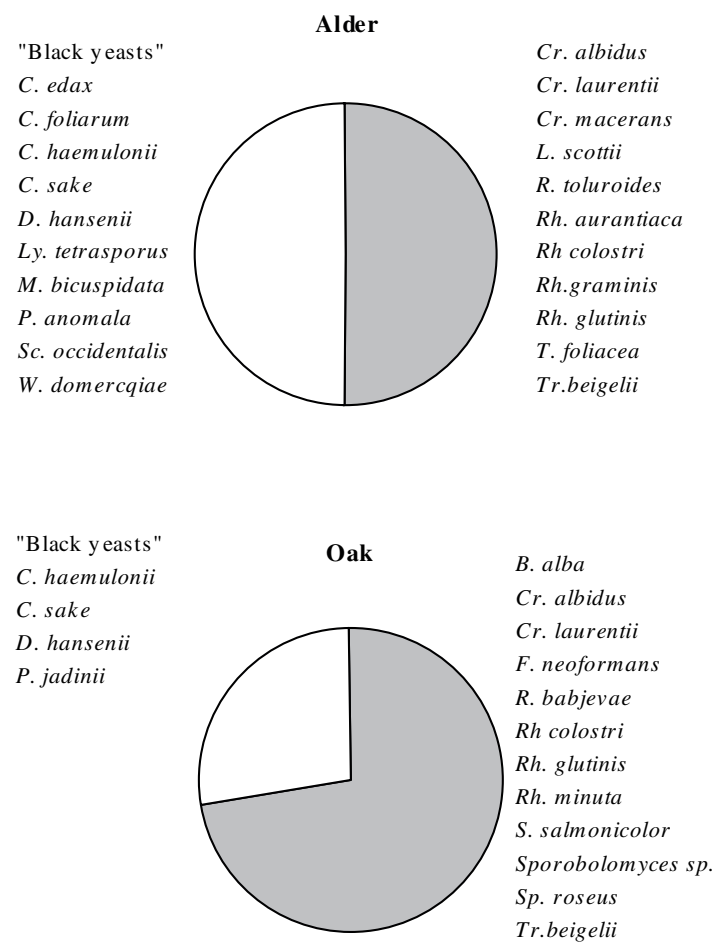

Eucalyptus B. alba

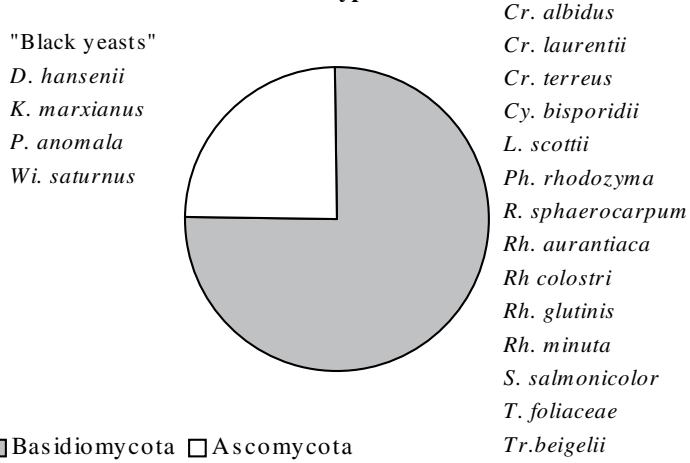

Figure 2. Percentages of basidiomycetous and ascomycetous yeasts species found in alder, oak and eucalyptus litters, and respective assemblages (left hand - Ascomycota; right hand - Basidiomycota)

litter type. In alder litter Candida edax (VAN DER WALT and E. E. NEL), R. foliorum (RUINEN) RODRIGUES DE MIRANDA and WEIJMAN and C. haemulonii (VAN UDEN and KolIPINSKI) were found, whereas in oak leaves $C$. sake (SAITO and ODA), Pichia jadinii (A. and R. SARTORY and WeIll and MeYer), R. minuta (SAITO), R. mucilaginosa (JÖRGENSEN), Sporobolomyces roseus (KLUYver and VAN NIEL), Sporidiobulus salmonicolor (Fell and TAllman) and Filobasidiella neoformans (KwON-CHUNG) were isolated. In eucalyptus litter C. albidus, 
Leucosporidium scottii (Fell, StAtzell, I. L. Hunter and PhAFF) and Trichosporon beigelii (KÜCHENMEISTER and RABENHORST) VUILLEMIN were commonly identified.

\subsection{Ergosterol Quantification}

Initial ergosterol values below to the detection limit (Fig. 1) indicated that the drying of the leaves after collection eliminated any phylloplane fungi. In alder, ergosterol increased rapidly until day 28 , slightly decreased by day 56 and remained constant until the end of the experiment. Of the three leaves, oak had the lowest ergosterol values $(<40 \mu \mathrm{g}$ ergosterol/g leaf dry mass) through almost the entire period until day 112, when it reached a maximum similar to that of alder leaves. Fungal biomass on eucalyptus reached the highest values (> 200 and $350 \mu \mathrm{g}$ ergosterol/g leaf dry mass, in days 56 and 112, respectively) of the three leaf species. There were significant differences in fungal biomass, expressed as ergosterol content, among leaf species $(\mathrm{F}=643.74, \mathrm{p}<0.0001)$ and decomposition times $(\mathrm{F}=203.82$, $\mathrm{p}<0.0001)$.
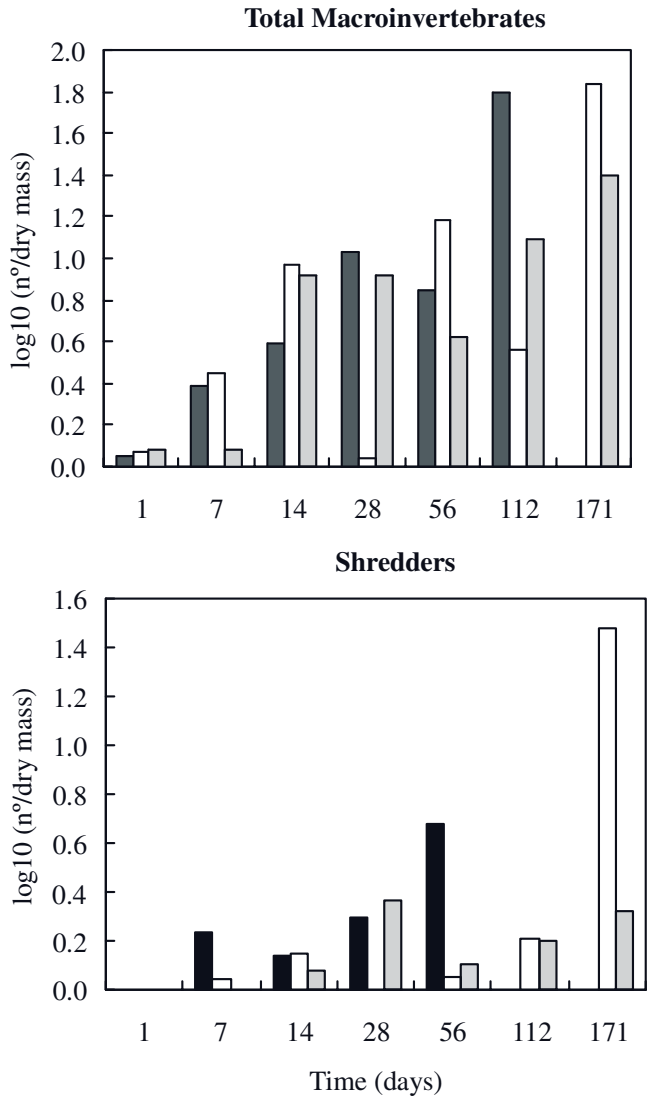

Alder $\square$ Oak $\square$ Eucalyptus

Figure 3. Total number $\left(\log _{10}\right)$ of invertebrates and only of shredders collected in the litterbags along decomposition. 


\subsection{Macroinvertebrate Colonisation}

Invertebrates rapidly colonised leaf bags (Fig. 3). The number of total individuals per dry leafs mass reached the highest values on days 112 (alder) and 171 (eucalyptus and oak). Macroinvertebrates per dry mass was significantly different among litters $(p<0.0001)$, and breakdown periods $(\mathrm{p}<0.0001)$. Maximum values occurred in alder leaves on day 112. Day 56 represented the maximum values of shredder densities, for this type of litter. The dominant feeding-groups in alder litter belonged to the collectors-gatherers and shredders. Predators and collector-filters were a minor component of the insect assemblages.

Shredder densities were significantly different among leaf types $(\mathrm{p}<0.0001)$ and breakdown periods $(\mathrm{p}<0.0001)$. This feeding-group was mostly abundant in alder leaves, representing $50 \%$ to $60 \%$ of total number of invertebrates in days 7 and 56 (Fig. 4), respectively. The stoneflies Amphinemura, Protonemura, Leuctra and Capnimeura were the dominant taxa.

Oak litter was dominated by collectors-gatherers, except for the latest collection dates (days 112 and 171), when shredders and collectors-filterers constituted an important part of the invertebrate assemblage. Eucalyptus leaves had the lowest percentages of shredders, notwithstanding their continuous presence from day 14 throughout the end of the study. In this litter type collector-filterers appeared from day 14 to the end of the experiment, reaching the major percentages in days 28 and 56 (>20\%).

\subsection{Discriminant Analyses}

The MDA analysis on the basis of yeast (grouping variable: leaf species) enabled us to identify six taxa that significantly contributed to a discrimination of the samples belonging to alder, eucalyptus and oak (total Wilks' Lambda 0.1919, $\mathrm{p}<0.05$ ). The species and their respective discriminatory powers are summarised in Table 1 , and the resulting CA diagram is shown in Figure 5A (the eigenvalues for the first two axes were 2.360 and 0.551 ). The discriminant species were $S$. roseus and $L$. scottii in oak and eucalyptus leaves, respectively. The yeast $R$. minuta colonised simultaneously these two litter types, but was absent from alder.

When time is considered as factor, the discrimination is more stringent (total Wilks' Lambda 0.0296, $\mathrm{p}<0.01$ ), and increases the distance between the grouping centroids (Fig. 5B, reflected by higher eigenvalues for the first two roots -7.729 and 2.877). Other species were now included in the model (Table 1). "Black yeasts" were pioneer species, exclusively present during the $1^{\text {st }}$ period, followed by $C$. haemulonii, P. anomala (E. C. HENSEN) and S. salmonicolor (restricted to the $2^{\text {nd }}$ period). The outstanding coloniser of the $1^{\text {st }}$ and the $2^{\text {nd }}$ periods was $S$. roseus (only in oak litter). C. laurentii, $R$. colostri and T. beigelii were ubiquitous, appearing in the three-colonisation periods.

The MDA grouping of invertebrate taxa separated by leaf species gave a Wilks' Lambda of 0.0892 , which means that the eight species included in the model had a significant discriminatory power $(\mathrm{p}<0.05)$. The Wilks' Lambda for each species and the resulting CA diagram which displays the samples for the first two roots are given in Table 2 and in Figure 5C, respectively (in the first two axes eigenvalues values were 5.280 and 0.784 ). From these analyses we may conclude that there are distinct preferences for each litter species. For instance, Euryophella iberica (KEFFERMÜLlER and DA TERRA) and Plectrocnemia laetabilis (MCLACHLAN) show preference for eucalyptus leaves, whereas P. meyeri (PICTET) and Baetis (juveniles) colonise mainly alder and oak leaves, respectively.

Analysing the discriminant effect caused by stage of colonisation, the MDA included seven taxa, resulting in a total Wilks' Lambda of 0.098 , which is highly significant $(\mathrm{p}<0.01)$. The values relative to this statistic for each species appear in Table 2. Thus, a 

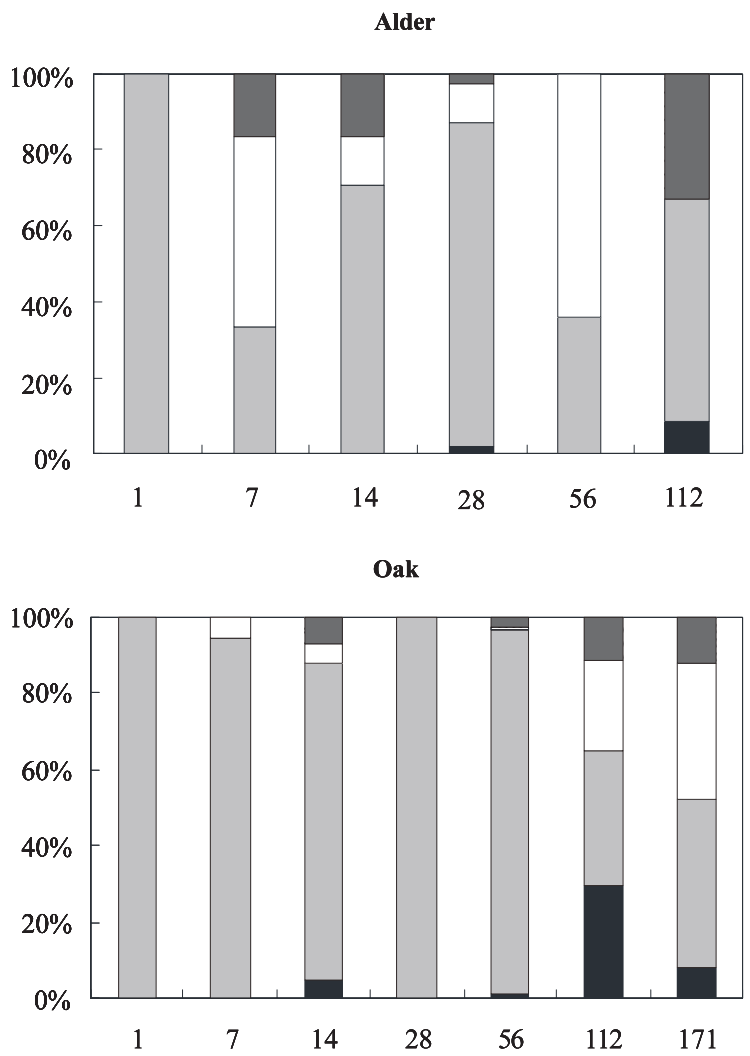

Eucalyptus

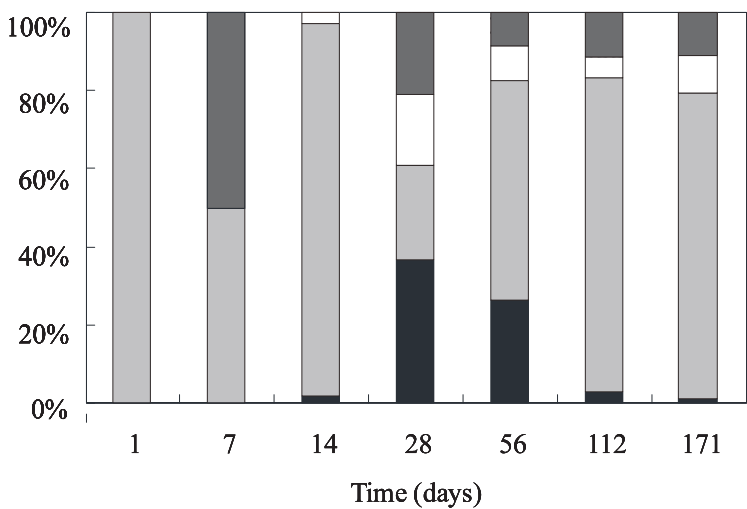

WCollector-gatherers $\square$ Shredders $\square$ Collector-filters $\square$ Predators

Figure 4. Percentages of macroinvertebrate feeding-groups in alder, oak and eucalyptus leaves collected in the litterbags along decomposition. 

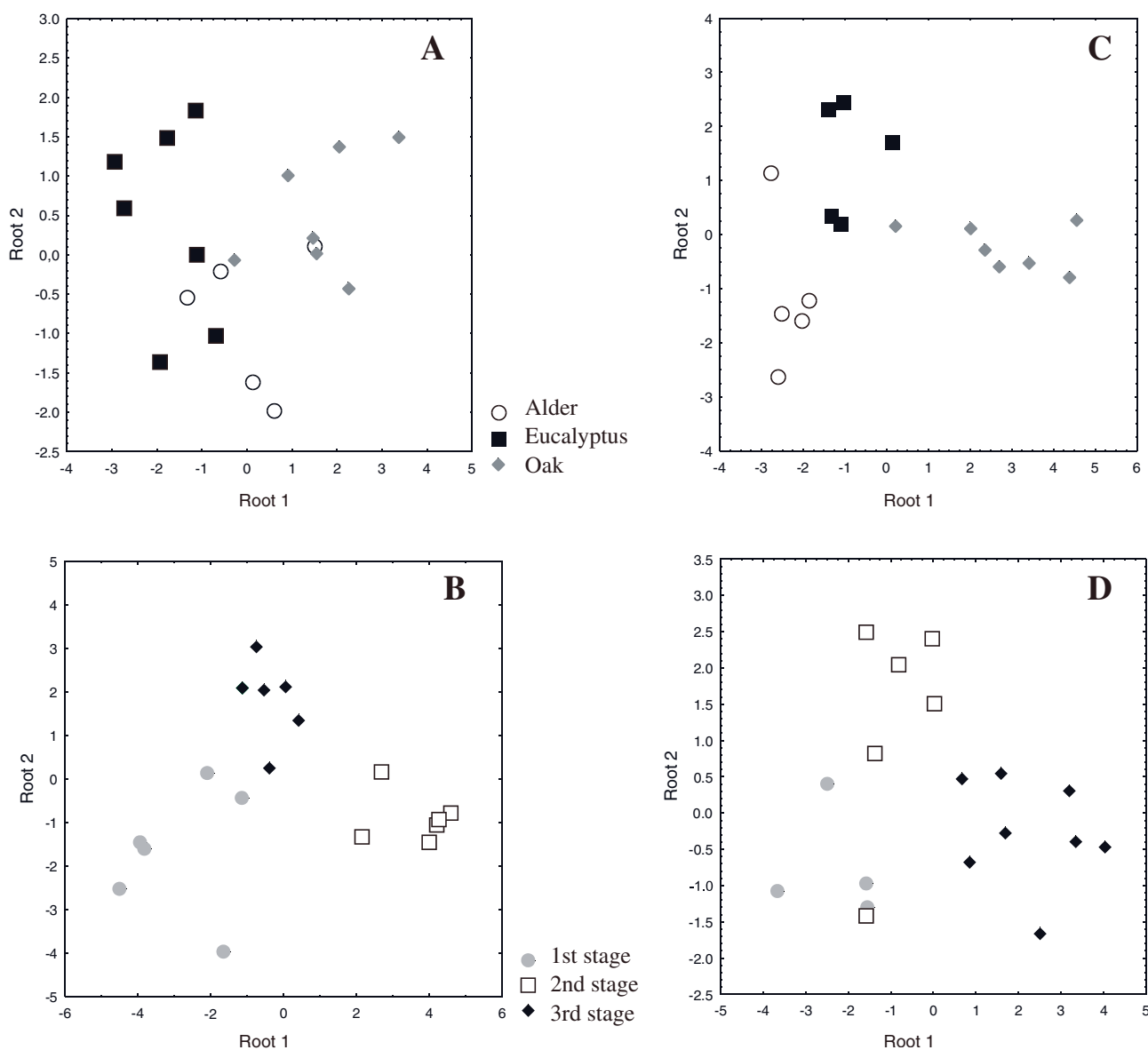

Figure 5. Diagram of MDA analysis of yeast and invertebrate species colonising leaf bags, according to leaf species (A for yeast, and $\mathbf{C}$ for invertebrate), and stages of decomposition (B for yeast, and $\mathbf{D}$ for invertebrate).

Table 1. Discriminatory power, assessed by the statistic Wilk's Lambda, for the yeast taxa included in the MDA model, considering the groups relying on leaf species or colonisation stage.

\section{Grouping variable Wilk's Lambda}

Leaf species

"Black yeasts"

Rh. minuta

D. hansenii

Cr. albidus

L. scottii

Sp. roseus
0.2351

0.2596

0.2622

0.3490

0.5498

0.3445
Grouping variable

Wilk's Lambda

Period of colonisation

Cr. laurentii

"Black yeasts"

0.0352

L. scottii

P. anomala

C. haemulonii

Tr. beigelii

Sp. roseus

$S$. salmonicolor

Rh. colostri
0.0356

0.0365

0.0418

0.0434

0.0466

0.0652

0.1034
0.0382 
Table 2. Discriminatory power, assessed by the statistic Wilk's Lambda, for the invertebrate taxa included in the MDA model, considering the groups relying on leaf species or colonisation stage.

\begin{tabular}{|c|c|c|c|}
\hline Grouping variable & Wilk's Lambda & Grouping variable & Wilk's Lambda \\
\hline Leaf species & & Period of colonisation & \\
\hline Euryophella iberica & 0.1085 & Callyarcis humilis & 0.1208 \\
\hline Pl. laetabilis & 0.1127 & Capnioneura libera/mitis & 0.1215 \\
\hline Protenemoura meyeri & 0.1375 & Haprophlebia fusca & 0.1376 \\
\hline Boyeria irene & 0.1437 & Chironomini g. sp. & 0.1416 \\
\hline Baetis sp. (juvenil) & 0.1536 & Atheryx sp. & 0.1423 \\
\hline Tanytarsini $g$. sp. & 0.1642 & Orthocladiinae & 0.1486 \\
\hline Tanypodinae $g$. sp. & 0.1690 & Amphinemura sulcicollis & 0.2374 \\
\hline Simulium sp. & 0.3540 & & \\
\hline
\end{tabular}

separation of stoneflies taxa along the sequence of colonisation is clear, e.g., the shredders Capnimeura libera (NAVAS)/mitis (DESPAX) appear during the first stages whereas Amphinemura sulcicollis (STEPHENS) is more abundant during the last ones. Such separation is also exhibited by the CA analysis displayed by Figure 5D (eigenvalues of 4.168 and 0.966 for the $1^{\text {st }}$ and $2^{\text {nd }}$ roots).

\section{Discussion}

The presence of yeasts in submerged leaf litter could be related to substrate nutrients or to nutrients encountered in water column. However, the latter hypothesis does not appear to be very credible, given the oligotrophic character of stream water. In our study, yeast colonisation of litters was rapid, and densities varied significantly $(p<0.0001)$ among different leaf types. Alder leaves had the highest yeast densities (maximum value at day 28), and exhibited an unstable pattern, when compared to oak and eucalyptus leaves. Similar results have been previously observed by SAMPAIO et al. (2001). Yeast dynamics also fluctuated considerably during the different stages of the decomposition period. Generally, after a rapid initial colonisation, yeast numbers stabilised until the final decay stages, with the exception of eucalyptus where, by day 171 , yeast densities had started to increase.

Our research confirmed that yeasts are positively correlated with total invertebrates $(\mathrm{r}=0.387 ; \mathrm{p}<0.0001)$ and collectors-gatherers $(\mathrm{r}=0.432 ; \mathrm{p}<0.0001)$. This last correlation seems interesting since gatherers are climbers and sprawlers (according to MERRIT and CUMMINS, 1984), which means that they can move over the leaf surface, and use the microbial biofilm accumulated thereon. As yeasts have higher protein contents $(65 \%$ dry mass) than filamentous fungi (40\% dry mass) they may provide more concentrated food (SCHWARTZ and LEATHEN, 1976) and therefore contribute to the conditioning effect.

The identity of the isolated yeast species made it clear that all were typical inhabitants of phylloplane and soils (PhAFF and StARMer, 1987; Polyakova et al., 2001). Many species appeared on two leaf species. For instance, R. minuta and Bullera alba (HANNA) were isolated both on oak and eucalyptus leaves. Species like T. foliacea (PERSOON), Rhodotorula aurantiaca (SAITO) and L. scottii were present in eucalypt and alder leaves. Many species, one the other hand, only appeared in one leaf type, e.g., S. roseus, R. babjevae (GoLUBEv) and F. neoformans were isolated only from oak leaves (Fig. 2), or S. salmonicolor, restricted to eucalyptus. Such different distribution of yeast populations among litters may be connected to distinct foliar chemical compositions. An early study showed a positive correlation between yeast densities and soluble sugars and a negative correlation between yeast den- 
sities and polyphenols (SAMPAIO et al., 2001), whose concentrations are affected during decomposition. Eucalyptus leaves have a poor nutrient content in terms of nitrogen (PozO, 1993), which limit microbial colonisation. Additionally, they are rich in polyphenols, condensed tannins and essential oils, substances that delay microbial attack as well insect feeding (СANHOTO and GRAÇA, 1999). The highest percentages of basidiomycetous yeasts on eucalypt and oak leaf litters could be related with the fact some of this yeasts (e.g. C. laurentii, $C$. terreus, $R$. glutinis, $R$. graminis and $R$. mucilaginosa) are able to degrade aromatic substances (MidDELHOven et al., 1992; SAMPAIO, 1999).

The discriminatory power of yeasts is more significant $(\mathrm{p}<0.01)$ when the MDA analysis is based on the decomposition phases. "Black yeasts" (whose representative species is Aureobasidium pullulans (DE BARY) ARNAUD) and B. alba, both common in senescent leaves and in soil (PHAFF and STARMER, 1987), disappeared after days 7 and 1 day, respectively. Presumably, they cannot compete with other fungi and/or are not adaptable to aquatic environments. Yeast species such as $C$. haemulonii, $C$. sake, $P$. anomala were only present in the $2^{\text {nd }}$ stage (days 14 and 28), while $S$. roseus, $S$. salmoniolor and $T$. beigelii appeared not sooner than the $3^{\text {rd }}$ stage (days 56 to 171). This clear differentiation of yeast assemblages decomposition phases, was probably due to differences on metabolic abilities of the yeast species, or even to different physiological capacities (some yeast species can grow in microaerophilic or anaerobic conditions).

Ergosterol concentrations values showed that fungal biomass increases to a maximum and then declines during alder leaf decay. The ergosterol content for alder leaves was relatively low in our study. Ergosterol content of A. glutinosa leaves exposed in a second order river achieved $300 \mu \mathrm{g} / \mathrm{g}$ ash free dry weight (GRAÇA et al., 2001) or $600 \mu \mathrm{g} / \mathrm{g}$ detritial dry mass, on the $56^{\text {th }}$ incubation day (GESSNER and CHAuvet, 1994). However, for a boreal stream, HAAPALA et al. (2001) reported maximum ergosterol values for grey alder (Alnus incata (L.) MoENCH) (day 33), of $118 \pm 41 \mu \mathrm{g} / \mathrm{g}$ dry mass, similar to the mean value obtained by us of $140 \mu \mathrm{g} / \mathrm{g}$ dry mass on day 28. Also, a previous study in Olo river (ABELHO, 1999) reported maximum ergosterol concentration of $200 \mu \mathrm{g} / \mathrm{g}$ dry mass for A. glutinosa leaves, incubated in coarse-bags.

Alder and eucalyptus leaves were more rapidly colonised by fungi than oak leaves. Eucalyptus leaves attained the maximum ergosterol content reached by alder on day 28, on day 56. BÄRLOCHER et al. (1995), and CHAUVET et al. (1997) also noticed a delay between fungal colonisation of alder and eucalypt leaves. The latter reached a higher value than alder (day 171, approximately $400 \mu \mathrm{g}$ ergosterol/g dry mass), probably because it can support higher fungal biomass (eucalypt leaves are thicker than alder leaves). Oak leaves differed somewhat from the others species (Fig. 1). GESSNER and CHAUvET (1994) also reported that ergosterol content in Quercus ilex (L.) was undetectable until 2 weeks, and the subsequent increases occurred slowly (the peak of $400 \mu \mathrm{g} / \mathrm{dray}$ mass concentration was reached 5 months later). However, the maximum values obtained by these authors and by SuberkropP (2001) for Q. alba (L.), were higher than the ones obtained in this study.

It is difficult to assess what percentage of the ergosterol can be attributed to the yeasts. Studies in ergosterol content in hyphomycetes and filamentous ascomycetes ranged from 2.3 to $11.9 \mu \mathrm{g}$ ergosterol per mg of dry mass (GESSNER and ChAUVET, 1993; NEwELL, 1994; PASANEN et al., 1999). PASANEN et al. (1999) also measured ergosterol content in basidiomycetous yeasts such as $C$. albidus, $R$. minuta and $R$. mucilaginosa. Comparing the ergosterol content per fungal dry mass, between yeasts and filamentous fungi, they concluded that the former had higher values than the latter. However, yeasts had lower ergosterol content in terms of fungal spore or cell - ergosterol has a good correlation with filamentous fungi, but underestimates the occurrence of yeast cells. In our work no correlation was found between ergosterol content and yeast densities.

Maximum shredder densities coincided with highest ergosterol content. In fact, we found a positive and significant correlation $(\mathrm{r}=0.408 ; \mathrm{p}=0.0011)$ between shredder densities and 
ergosterol content. This confirms similar observations by HAAPALA et al. (2001) for alder, willow and birch.

From the discriminant analysis based on grouping variable leaf litter, we can assume that macroinvertebrate communities are influenced by litter type $(p<0.05)$. However, from the discriminatory insect species obtained, it is impossible to determine if the occupied substrates were primarily used as food (direct feeding) or as shelter. Simulium sp., a collectorfilterer, was confined to oak and eucalyptus leaves, probably because these leaves are more stable, and thus provides a preferred attachment site. BASAGUREN and POZO (1994), and SAMPAIO et al. (2001) reported the same preference. Since P. meyeri is the only shredder present, we believe that the type of leaves has only an indirect effect on the presence of most invertebrates. The evidence for leaf preferences of some invertebrates, in spite of the opportunistic character of most colonisers (KING et al., 1987), has already been pointed out for oligotrophic headwaters streams (CANHOTO and GRAÇA, 1995).

The distribution of invertebrate species was also variable during the process of decomposition $(\mathrm{p}<0.01)$. The species $C$. libera/mitis appeared early, whereas A. sulcicollis was detected at latter stages. This fact may be due to chemical alterations in the substrate affecting its palatability (both invertebrates are shredders), or to different growth periods. HAAPALA et al. (2001), identified a similar pattern involving A. borealis and P. meyeri; the first having a growth period in Winter/Spring, and the latter in Autumn/Winter. As our study took place from final January to early June, it is possible that the shredders had different growing periods. Discriminant analysis also suggested that collector-gatherers such as Callyarcis humilis (EATON), Habrophlebia fusca (CURTIS), Orthocladiinae and Chironomini played an important role in the last two breakdown stages.

The most telling conclusion to be drawn from our study was the fact that yeast, total invertebrates and shredder densities vary with the type of litter and the stage in the breakdown process. Furthermore, invertebrate - even more so than yeast - species composition, can be discriminating for alder, oak and eucalyptus litters. However, interpretation of the last points requires caution, since invertebrate colonisation, as mentioned, may not be directly linked to leaf chemical composition. Evidence suggests that both yeasts and invertebrates can distinguish between breakdown stages (see Fig. 5). Our results seem to indicate, however, that yeasts are more sensitive to stages of decay than invertebrates.

\section{Acknowledgements}

The authors thank Fernando FerReIRA for fieldwork assistance, Sofia SAMPAio for revising the English of the final draft of this paper and are grateful for helpful comments provided by two anonymous reviewers.

\section{References}

Abelho, M. and M. A. S. GraçA, 1998: Litter in a first-order stream of a temperate deciduous forest (Margaraça Forest, Central Portugal). - Hydrobiologia 386: 147-152.

ABelho, M., 1999: Once upon a time a leaf... From litterfall to breakdown in streams. Ph.D. Thesis. Coimbra University. Coimbra. Portugal, 183 p.

ANDERson, N. H. and J. R. SEDell, 1979: Detritus processing by macroinvertebrates in stream ecosystems. - Ann. Rev. Entomology 24: 351-377.

BÄRLOCHER, F., 1985: The role of fungi in the nutrition of stream invertebrates. - Bot. J. Linn. Soc. 91: 83-94.

BÄrlocher, F., C. CANHoto and M. A. S. GraÇA, 1995: Fungal colonization of alder and eucalyptus leaves in two streams in Central Portugal. - Arch. Hydrobiol. 133: 457-470.

Basuguren, A. and J. Pozo, 1994: Leaf litter processing of alder and eucalyptus in the Agüera stream system (Northern Spain). II. Macroinvertebrates associated. - Arch. Hydrobiol. 132: 57-68. 
Biely, P., Z. KrátKy, A. KockovÁ-KratochvílovÁ and S. Bauer, 1978: Xylan-degrading activity in yeasts: growth on xylose, xylan and hemicellulose. - Folia. Microbiologica 23: 366-371.

CANHOto, C. and M. A. S. GRAÇA, 1995: Food value of introduced eucalypt leaves for a Mediterranean stream detritivore: Tipula lateralis. - Freshwat. Biol. 34: 209 - 214.

CANHoto, C. and M. A. S. GRAÇA, 1999: Leaf barriers to fungal colonization and shredders (Tipula lateralis) consumption of decomposing Eucalyptus globulus. - Microb. Ecol. 37: 163-172.

Chamier, A. C., 1987: Effect of $\mathrm{pH}$ on microbial degradation of leaf litter in seven streams of the English Lake District: - Oecologia 71: 491-500.

Chauvet, E., E. Fabre, A. Elósegui and J. Pozo, 1997: The impact of eucalypt on the leaf-associated aquatic hyphomycetes in Spanish streams. - Can. J. Bot. 75: 880-887.

COLLIER, K. J. and J. N. HallidAy, 2000: Macroinvertebrate-wood association during decay of plantation pine in New Zealand pumice-bed streams: stable habitat or trophic subsidy? - J. N. Am. Benthol. Soc. 19: 94-111.

Cummins, K. W. and M. J. Klug, 1979: Feeding ecology of stream invertebrates. - Annu. Rev. Ecol. Syst. 10: $147-186$.

DENNIS, C., 1972: Breakdown of cellulose by yeast. - J. Gen. Microbiol. 71: 409-411.

FlanNigan, B., 1970: Degradation of arabinoxylan and carboxymethyl cellulose by fungi isolated from barley kernels. - Transactions of the British Mycol. Soc. 55: 277-281.

FRANKLAND, J. C., 1998: Fungal succession - unravelling the unpredictable. - Mycol. Res. 102: 1-15.

Gessner, M. O. and E. CHAUvet, 1993: Ergosterol-to-biomass conversion factors for aquatic hyphomycetes of stream microfungi in controlling breakdown rates of leaf litter. - Ecology $\mathbf{7 5}$ : $1807-1817$.

GESSNER, M. O. and E. CHAUVET, 1994: Importance of stream microfungi in controlling breakdown rates of leaf litter. - Appl. Environ. Microbiol. 59: 502 - 507.

Gessner, M. O. and A. L. SChMitT, 1996: Use of solid-phase extraction to determine ergosterol concentration in plant tissue colonized by fungi. - Appl. Environ. Ecol. 62: 415-419.

Gessner, M. O., E. Chauvet and M. Dobson, 1999: A perspective on leaf litter breakdown in streams. - Oikos 85: 377-384.

Graça, M. A. S., L. Maltby and P. CALOw, 1993: Importance of fungi in the diet of Gammarus pulex and Asellus aquaticus I: feeding strategies. - Oecologia 93: 139-144.

GraçA, M. A. S., R. C. F. FERREIRA and C. N. CoImBRA, 2001: Litter processing along a stream gradient: the role of invertebrates and decomposers. - J. N. Am. Benthol. Soc.: 20: 408-420.

HaApala, A., T. MuOTKA and A. MarkKola, 2001: Breakdown and macroinvertebrate and fungal colonization of alder, birch, and willow leaves in a boreal forest stream. - J. N. Am. Benthol. Soc.: 20: 395-407.

JAGER, E. S., F. C. WeHner and L. Korsten, 2001: Microbial ecology of the mango phylloplane. Microb. Ecol. 42: 201-207.

JimÉnez, M., A. E. GonZÁlez, M. J. Martínez and A. T. Martínez, 1991: Screening of yeasts isolated from decayed wood for lignocellulose-degrading enzyme activities. - Mycol. Res. 95: 1299-1302.

King, H. G. C., M. P. Henshall-Howard, J. A. Day and B. R. Davies, 1987: Leaf-pack dynamics in a southern African mountain stream. - Freshwat. Biol. 18: 325-340.

Lachance, M.-A. and W. T. Starmer, 1998: Ecology of yeasts. - In: . Kurtzman and Fell (eds). The Yeasts, a Taxonomic Study, $4^{\text {th }}$ ed. Amesterdam, Elsevier Science.

Lachance, M.-A., W. T. Starmer, C. A. Rosa, J. M. Bowles, J. S. F. Barker and D. H. Jansen, 2001: Biogeography of the yeast of ephemeral flowers and their insects. - FEMS Yeast Res. 1: 1-8.

Melillo, J. M., R. J. Naiman, J. D. Aber and A. E. Linkins, 1984: Factors controlling mass loss and nitrogen dynamics on plant litter decaying in northern streams. - Bull. Mar. Sci. 35: 341-356.

MerRit, R. W. and K. W. Cummins, 1984: An introduction to aquatic insects of North America. $2^{\text {nd }}$ ed. Kendall/Hunt, (eds.) Dubuque, USA.

Middelhoven, W. J., M. KoorevaAR and G. W. Schuur, 1992: Degradation of benzene compounds by yeasts in acidic soils. - Plant Soil 145: 37-43.

Minshall, G. W., 1967: Role of allochtonous detritus in the trophic structure of a woodland springbrook community. - Ecology 48: 139-149.

Newell, S. Y., 1994: Total and free ergosterol in mycelia of saltmarsh ascomycetes with access to whole leaves or aqueous extracts of leaves. - Appl. Environ. Microbiol. 60: 3479-3482.

Pasanen, A-L., K. Yli-Pietilä, P. Pasanen, P. Kalliokoski and J. Tarhanen, 1999: Ergosterol content in various fungal species and biocontaminated building materials. - Appl. Environ. Microbiol. 65: $138-142$. 
Petersen, R. C. and K. W. Cummins, 1974: Leaf processing in a woodland stream. - Freshwat. Biol. 4: 343-368.

PhafF, H. J. and W. T. StARMER, 1987: Yeasts associated with plants, insects and soil and microbial. In: Rose and HARrison (eds). The Yeasts, Vol. I London, Academic Press.

Polyakova, A. V., I. Y. Chernov and N. S. PANikov, 2001: Yeast diversity in hydromorphic soils with reference to a grass-sphagnum wetland in western Siberia and a Hummocky Tundra Region of Cape Barrow (Alaska). - Microbiol. 70: 617-622.

Pozo, J., 1993: Leaf litter processing of alder and eucalyptus in the Agüera stream system (North Spain). I. Chemical changes. - Arch. Hydrobiol. 127: 299-317.

RoBinson, C. T., M. O. GesSNER and J. V. WARD, 1998: Leaf breakdown and associated macroinvertebrates in alpine glacial streams. - Int. Rev. Hydrobiol. 86: 527-540.

SAMPAIO, A., R. CORTES and C. LeÃo, 2001: Invertebrate and microbial colonisation in native and exotic leaf litter species in a mountain stream. - Int. Rev. Hydrobiol. 86: 527-540.

SAMPAIO, J. P., 1999: Utilization of low molecular weight aromatic compounds by heterobasidiomycetous yeasts: taxonomic implications. - Can. J. Microbiol. 45: 491-512.

Schwartz, R. D. and W. W. Leathen, 1976: Petroleum microbiology. - In: Miller and Litsky (eds). Industrial Microbiology, $1^{\text {st }}$ ed., USA, McGraw-Hill Book Company.

Spencer, J. F. T., P. A. Gorin and N. R. GARDNER, 1970: Yeast isolated from the South Saskatchewan, a polluted river. - Can. J. Microbiol. 16: 1051-1057.

Statistica $^{\text {TM, 1999: Statistica }}{ }^{\text {TM}}$. Vol. III: Statistics II. StatSoft®.

Statview, 1992-1996: Statview for Windows, Version 4.53. Abacus Concepts, Inc., Copyright@.

SubERKROPP, K., 2001: Fungal growth, production, and sporulation during leaf decomposition in two streams. - Appl. Environ. Microbiol. 67: 5063-5068.

VENTURINI, M. E., R. ORIA and D. Blanco, 2002: Microflora of two varieties of sweet cherries: Burlat and Sweetheart. - Food Microbiol. 19: 15- 21.

YARROW, D., 1998: Methods for the isolation, maintenance and identification of yeasts. - In: KURTZMAN and Fell (eds). The Yeasts, a Taxonomic Study, $4^{\text {th }}$ ed., Amesterdam, Elsevier Science. 